\title{
NON-ALCOHOLIC FATTY LIVER DISEASE AND HYPERTENSION: CLINICAL VARIABILITY OF COMORBIDITY
}

\author{
Rozhdestvenska A., Babak O., Zhelezniakova N. \\ Kharkiv National Medical University, Ukraine \\ https://doi.org/10.35339/ic.7.3.131-138
}

\begin{abstract}
Introduction. Non-alcoholic fatty liver disease (NAFLD) is one of the most common chronic liver diseases; and considerable attention is paid to the comorbidity of NAFLD with hypertension (HT), which affects around one-third of the world's population. The combination of NAFLD with hypertension has been suggested to have a mutual potentiating effect, and hypertension affects the severity of NAFLD. The purpose: to study the features of the clinical manifestation of NAFLD in patients with hypertension. Materials and methods. The study included 115 patients with NAFLD at the stage of nonalcoholic steatohepatitis. The main group consisted of 63 patients with NAFLD and HT, the comparison group included 52 patients with isolated NAFLD, and the control group was composed of 20 healthy volunteers. The patients underwent anthropometric measurements, evaluation of biochemical markers of liver functional activity, lipid profile and carbohydrate metabolism changes, C-reactive protein (CRP) levels. Results. A significant increase in the proportion of patients with active complaints in the group of patients with NAFLD with HT (subjective signs of liver damage, manifestations of dyspeptic and asthenic syndrome) was detected. Significant differences were found in almost all anthropometric indicators in both groups of patients with NAFLD in comparison with the control group. The level of CRP had significant differences and was $7.90 \mathrm{mg} / \mathrm{l}(95 \% \mathrm{CI}=7.96-8.75 \mathrm{mg} / \mathrm{l}), 6.55 \mathrm{mg} / \mathrm{l}(95 \% \mathrm{CI}=6.47-7.57 \mathrm{mg} / \mathrm{l})$ and $2.07(95 \% \mathrm{CI}=1.83-2.85 \mathrm{mg} / \mathrm{l})$ in patients with NAFLD and HT, isolated NAFLD and the control group, respectively $(\mathrm{p}<0.001)$. Fasting glucose levels were significantly higher in both groups of examined patients with NAFLD compared with controls. Significant differences were found in the levels of total cholesterol, VLDL cholesterol, HDL cholesterol and atherogenic factor in patients with NAFLD depending on concomitant HT. There was no significant difference between LDL cholesterol and triglycerides in the two groups of patients with NAFLD. Conclusions. Based on the obtained data, it can be stated that GC in patients with NAFLD determines important deviations in the clinical manifestation of the disease and can be considered as a trigger factor for the progression of NAFLD.

Keywords: non-alcoholic fatty liver disease, NAFLD, hypertension, NAFLD with HT, NAFLD comorbidity, clinical variability, clinical manifestation.
\end{abstract}

\section{Introduction}

Non-alcoholic fatty liver disease (NAFLD) is one of the most common metabolic pathologies. Manifestation of NAFLD is the accumulation of lipids in the liver with the development of steatosis and fibrosis of the liver parenchyma. NAFLD differs in stages, from simple steatosis pathological processes can progress to non-alcoholic

Corresponding Author:

Anastasiia Rozhdestvenska MD, PhD student

of the Department of internal medicine №1 .

Kharkiv National Medical University, Ukraine.

E-mail: rozhdestvenska.anastasiia@gmail.com steatohepatitis (NASH), fibrosis and cirrhosis of the liver. In the final stages, the pathology can lead to hepatocellular carcinoma development [16].

The incidence of NAFLD is about $70 \%$ among chronic liver diseases, affecting 17 to $40 \%$ of the adult population in different countries and $20-30 \%$ of the European population [4]. Considerable attention is paid to the comorbidity of NAFLD with cardiovascular diseases, especially hypertension (HT). High blood pressure is found in about $30 \%$ of the world's population, it is determined by one of the most significant risk factors for cardiovascular mortality [12]. 
According to several studies, NAFLD and hypertension have the effect of mutual potentiation in combination. Hypertension affects the severity of NAFLD and the rate of fibrosis in the liver parenchyma, and NAFLD contributes to the progression of hypertension and causes secondary damage to target organs [5].

It is known that NAFLD is a hepatic manifestation of the metabolic syndrome, one of the components of which is hypertension. In this regard, hypertension doubles the risk of liver fibrosis progression $[14 ; 13 ; 17]$. The association between NAFLD and HT has also been shown to be independent of other manifestations of the metabolic syndrome, such as overweight and insulin resistance. Changes in eating behavior, hypokinesia, overweight and smoking were identified among the main common risk factors for the two pathologies [15]. In the pathogenesis of NAFLD, systemic inflammation plays an important role [20]. A significant increase in C-reactive protein and other inflammatory markers is observed in patients with NAFLD, especially at the stage of NASH [6].

Research data indicate the activation of inflammatory processes associated with HT. Endothelial dysfunction, tissue hypoxia, and immune response changes play a key role in the inflammation pathogenesis in such patients [19].

Lipid profile changes has been drawing considerable attention in the study of patients with both NAFLD and HT. The risk of mortality in patients with hypertension is defined as increased in the presence of hypercholesterolemia and hypertriglyceridemia [21]. Other studies indicate an increased risk of NAFLD progression with elevated levels of triglycerides (TG), low-density lipoprotein (LDL) cholesterol, very low-density lipoprotein (VLDL) cholesterol and concomitant reduction of high-density lipoprotein (HDL) cholesterol [7; 9].

Common pathogenic pathways associated with the activation of the renin-angiotensinaldosterone system, systemic inflammation, oxidative stress, apoptosis, and endotoxemia determine higher morbidity and mortality in patients with a combination of NAFLD and HT. Several studies note that even elevated normal blood pressure figures predict the development and progression of NAFLD, and confirmed NAFLD significantly increases the risk of developing hypertension $[19 ; 3]$.

\section{Purposes, subjects and methods}

2.1. The purpose of the research was to study the features of the clinical manifestation of non-alcoholic fatty liver disease in patients with hypertension.

\subsection{Subjects and methods}

115 , of them 57 men and 58 women, aged 38 to 59 years $(n=115 ; M=48.3 ; 95 \% C I=47.4$ 49.3) s with verified NAFLD at the stage of nonalcoholic steatohepatitis in combination with and without hypertension were examined. According to the presence of hypertension, the patients were divided into two groups. The main group included patients with NAFLD in combination with HT ( $\mathrm{n}=63 ; 32$ men and 31 women), aged 38 to 59 years $(\mathrm{M}=48.4 ; 95 \% \mathrm{CI}=47.2-49.6)$. The comparison group consisted of patients with isolated fatty liver ( $\mathrm{n}=52 ; 25$ men and 27 women) aged 39 to 59 years $(\mathrm{Me}=48.3 ; 95 \% \mathrm{CI}=46.8-49.8)$. The control group was composed of 20 healthy volunteers, including 12 women and 8 men aged 38 to 56 years $(\mathrm{Me}=47.1 ; 95 \% \mathrm{CI}=45.1-49.1)$.

The duration of NAFLD in patients with comorbid NAFL ranged from 2 to 16 years $(\mathrm{Me}=6.6 ; 95 \% \mathrm{CI}=5.8-7.3)$, and hypertension in this group of patients was diagnosed from 2 to 19 years ago $(\mathrm{Me}=8.4$ years; $95 \% \mathrm{CI}=7.3-9.5)$. The duration of NAFLD in the group of patients with an isolated fatty liver was also in the range from 2 to 16 years, but on average was insignificantly longer than in the group of comorbid course $(\mathrm{Me}=7.8 ; 95 \% \mathrm{CI}=6.7-8.8 ; \mathrm{p}=0.086)$.

NAFLD was diagnosed in the previous stages of managing the patients according to the Order of the Ministry of Health of Ukraine as of 06/11/ 2014, No. 826 "Unified clinical protocol of primary, secondary (specialized) medical care: nonalcoholic steatohepatitis" and EASL-EASD-EASO Clinical Practice Guidelines, 2016. Hypertension was diagnosed in the previous stages of managing patients according to the Order of the Ministry of Health of Ukraine No. 384 as of 24/05/2012, "Unified clinical protocol for medical care in arterial hypertension" and criteria of European (ESH / ESC) clinical guidelines for arterial hypertension, 2018.

The overall study included anthropometric measurements - height, weight, waist (WC) and thigh circumference (TC) were determined by standard methods. Body mass index (BMI) and thigh to waist ratio (TWaR) were also calculated according to generally accepted formulas. Biochemical parameters of liver functional activity were determined by spectrophotometric and colometric methods (including alanine aminotransferase (ALT), aspartate aminotransferase (AST), alkaline phosphatase (ALP), gammaglutamyl transpeptidase (GGT)). In addition, the 
levels of of lipid metabolism (total cholesterol, triglycerides, VLDL cholesterol, HDL cholesterol) were determines by the enzymatic method on a biochemical analyzer. Low-density lipoprotein cholesterol (LDL cholesterol) was calculated by Friedewald W.T. (1972) and atherogenic coefficient was determined by the following formula, proposed by A. N. Klimov (1982): Total cholesterol - HDL cholesterol / HDL cholesterol. In order to assess carbohydrate metabolism, glucose levels were determined using the glucose oxidant method. The level of acute-phase marker of inflammation, C-reactive protein (CRP), was determined using a highly sensitive method (hs-CRP ELISA) (Biomerica, USA). All statistical processing of obtained results was performed using computer software packages "Excel 2019" (Microsoft), "Statistica 8.0. for Windows" (StatSoft Inc.). Continuous variables are presented as mean (M) or median (Me) depending on the correspondence with the normal distribution and confidence intervals with established reliability $\gamma=0.95(95 \%$ CI). Non-parametric methods were used to determine the relationships between risk factors, clinical and laboratory parameters. Spearman's rank correlation coefficient was determined and Chaddock scale was used to determine the strength of the relationship. The statistical significance of differences in relative indicators was determined using Pearson's chisquared test. The Manng Whitney U-test was used to determine the difference between the two independent samples by the trait level. The maximum allowable probability of committing a type I error ( $p$-value) was established as the value of the level of statistical significance less or equal than 0.05 .

\section{Conflict of interests}

The authors of the article declare no conflict of interest.

\section{Results}

Typical complaints of patients with NAFLD with or without hypertension were general weakness, fatigue, loss of appetite, right upper quadrant discomfort and pain, signs of emotional instability (emotional lability, sleep disturbances). The analysis of complaints revealed a significant increase in the proportion of patients with active complaints in the group of patients with NAFLD against a background of hypertension (Table 1).

The levels of systolic blood pressure (SBP) and diastolic blood pressure (DBP) in patients

The frequency of the main complaints

Table 1 in NAFLD patients depending on the presence of $H T, n, \%$

\begin{tabular}{|c|c|c|c|c|c|}
\hline \multirow[t]{2}{*}{ Complaints } & \multicolumn{2}{|c|}{$\begin{array}{l}\text { NAFLD and HT } \\
(n=63)\end{array}$} & \multicolumn{2}{|c|}{$\begin{array}{l}\text { NAFLD } \\
(n=52)\end{array}$} & \multirow{2}{*}{$\begin{array}{l}\text { Probability of difference (Pearson's } \\
\text { chi-squared test results) }\end{array}$} \\
\hline & $\mathrm{n}$ & $\%$ & $n$ & $\%$ & \\
\hline General weakness & 43 & 68.25 & 13 & 25 & $\begin{array}{c}d f=1 \\
\chi^{2}=21.333 \\
p<0.001\end{array}$ \\
\hline Rapid fatigue & 51 & 80.95 & 14 & 26.92 & $\begin{array}{c}\mathrm{df}=1 \\
\chi^{2}=33.839 \\
p<0.001\end{array}$ \\
\hline Impaired appetite & 50 & 79.37 & 25 & 48.08 & $\begin{array}{c}d f=1 \\
\chi^{2}=12.294 \\
p<0.001\end{array}$ \\
\hline Early satiety & 38 & 60.32 & 18 & 34.62 & $\begin{array}{c}d f=1 \\
\chi^{2}=7.532 \\
p=0.007\end{array}$ \\
\hline $\begin{array}{l}\text { Right upper } \\
\text { quadrant discomfort }\end{array}$ & 42 & 66.67 & 22 & 42.31 & $\begin{array}{c}\mathrm{df}=1 \\
\chi^{2}=6.849 \\
p=0.009\end{array}$ \\
\hline $\begin{array}{l}\text { Right upper } \\
\text { quadrant pain }\end{array}$ & 12 & 19.05 & 6 & 11.54 & $\begin{array}{c}d f=1 \\
\chi^{2}=1.217 \\
p=0.271\end{array}$ \\
\hline Telangiectasia & 15 & 23.81 & 6 & 11.54 & $\begin{array}{c}d f=1 \\
\chi^{2}=2.874 \\
p=0.091\end{array}$ \\
\hline Sleep disorders & 42 & 66.67 & 13 & 25 & $\begin{array}{c}d f=1 \\
\chi^{2}=19.820 \\
p<0.001\end{array}$ \\
\hline Emotional lability & 47 & 74.6 & 12 & 23.08 & $\begin{array}{c}d f=1 \\
\chi^{2}=30.273 \\
p<0.001\end{array}$ \\
\hline
\end{tabular}


with NAFLD and HT naturally had significantly difference in comparison with NAFLD patients without HT and the control group. The figures of DBP in the comparison group were significantly lower than in the control group (Table 2). values that was $2.07 \mathrm{mg} / \mathrm{l}(95 \% \mathrm{CI}=1,83-2.85$ $\mathrm{mg} / \mathrm{l})$ in $3.8(\mathrm{p}<0.001)$ and $3.2(\mathrm{p}<0.001)$ times, respectively (Figure).

Evaluation of metabolic profile revealed changes in one of the main indicators of

Table 2

Blood pressure numbers in NAFLD patients depending on the presence of $\mathrm{HT}, \mathrm{mm} \mathrm{Hg}$

\begin{tabular}{|c|c|c|c|c|}
\hline Indicator & $\begin{array}{c}\text { NAFLD and } \mathrm{HT} \\
(\mathrm{n}=63)\end{array}$ & $\begin{array}{c}\text { NAFLD } \\
(\mathrm{n}=52)\end{array}$ & $\begin{array}{c}\text { Control group } \\
(\mathrm{n}=20)\end{array}$ & Reliability between groups \\
\hline SBP, mm Hg & $140(95 \% \mathrm{Cl}=$ & $120(95 \% \mathrm{Cl}=$ & $123(95 \% \mathrm{Cl}=$ & $\begin{array}{c}\mathrm{p}_{1-2}<0.001 \\
\mathrm{p}_{1-3}<0.001 \\
\mathrm{p}_{2-3}=0.059\end{array}$ \\
\hline \multirow{2}{*}{ DBP, mm Hg } & $137.86-140.55)$ & $120.83-122.24)$ & $121.94-126.56)$ & $\begin{array}{c}\mathrm{p}_{1-2}<0.001 \\
\mathrm{p}_{1-3}<0.001 \\
\mathrm{p}_{2-3}=0.004\end{array}$ \\
\hline
\end{tabular}

Note: $\mathrm{p}<0,05-$ the difference is statistically significant between groups;

$\mathrm{p}_{1-2}$ - the difference between the NAFLD + HT group and the isolated NAFLD group;

$\mathrm{p}_{1-3}$ - the difference between the NAFLD + HT group and the control group;

$\mathrm{p}_{2-3}$ - the difference between the isolated NAFLD group and the control group.

No significant differences in anthropometric parameters of patients with comorbid and isolated NAFLD were found. Meanwhile, significant differences were found in comparison with the control group in almost all indicators of both the main and the comparison group, except for the thighs circumference. This was a reflection of the regular prevalence of abdominal obesity in patients with NAFLD (Table 3). carbohydrate metabolism: fasting glucose levels were significantly higher than in patients with NAFLD and HT, which was $5.87 \mathrm{mmol} / \mathrm{l}(95 \%$ $\mathrm{CI}=5.76-5.98 \mathrm{mmol} / \mathrm{l})(\mathrm{p}<0.001)$ and in the comparison group, where the figure reached $5.62 \mathrm{mmol} / 1(95 \% \mathrm{CI}=5.43-5.60 \mathrm{mmol} / \mathrm{l})(\mathrm{p}<0.001)$ in relation to the control values $4.52 \mathrm{mmol} / 1(95 \%$ $\mathrm{CI}=4.48-4.61 \mathrm{mmol} / \mathrm{l})$. Comparative analysis of glucose levels in the examined groups of

Table 3

Anthropometric parameters in NAFLD patients depending on the presence of $H T, \mathrm{~cm}$

\begin{tabular}{|c|c|c|c|c|}
\hline Indicator & $\begin{array}{l}\text { NAFLD and HT } \\
(n=63)\end{array}$ & $\begin{array}{l}\text { NAFLD } \\
(n=52)\end{array}$ & $\begin{array}{l}\text { Control group } \\
(n=20)\end{array}$ & Reliability between groups \\
\hline BMI, cm & $\begin{array}{c}26.9 \\
(95 \% \mathrm{Cl}= \\
24.45-29.34)\end{array}$ & $\begin{array}{c}25.1 \\
(95 \% \mathrm{Cl}= \\
25.38-26.56)\end{array}$ & $\begin{array}{c}22.7 \\
(95 \% \mathrm{Cl}= \\
22.41-23.46) \\
\end{array}$ & $\begin{array}{l}\mathrm{p}_{1-2}=0.477 \\
\mathrm{p}_{1-3}<0.001 \\
\mathrm{p}_{2-3}<0.001\end{array}$ \\
\hline WC, $\mathrm{cm}$ & $\begin{array}{c}86.0 \\
(95 \% \mathrm{Cl}= \\
82.9-87.4) \\
\end{array}$ & $\begin{array}{c}82.5 \\
(95 \% \mathrm{Cl}= \\
81.01-85.87)\end{array}$ & $\begin{array}{c}71.40 \\
(95 \% \mathrm{Cl}= \\
67.57-75.13)\end{array}$ & $\begin{array}{l}p_{1-2}=0.302 \\
p_{1-3}<0.001 \\
p_{2-3}<0.001\end{array}$ \\
\hline $\begin{array}{l}\text { Thigh to waist ratio } \\
\text { (TWaR) }\end{array}$ & $\begin{array}{c}0.89 \\
(95 \% \mathrm{Cl}= \\
0.86-0.90)\end{array}$ & $\begin{array}{c}0.86 \\
(95 \% \mathrm{Cl}= \\
0.84-0.89)\end{array}$ & $\begin{array}{c}0.76 \\
(95 \% \mathrm{Cl}= \\
0.74-0.77)\end{array}$ & $\begin{array}{l}\mathrm{p}_{1-2}=0.395 \\
\mathrm{p}_{1-3}<0.001 \\
\mathrm{p}_{2-3}<0.001\end{array}$ \\
\hline
\end{tabular}

Note: $p<0,05-$ the difference is statistically significant between groups;

$\mathrm{p}_{1-2}$ - the difference between the NAFLD + HT group and the isolated NAFLD group;

$\mathrm{p}_{1-3}$ - the difference between the NAFLD + HT group and the control group;

${ }_{\mathrm{p} 2-3}$ - the difference between the isolated NAFLD group and the control group.

Determination of C-reactive protein levels as a non-specific marker of inflammatory processes also revealed a significant difference in its content among the groups. In patients of the main group C-reactive protein level was $7.90 \mathrm{mg} / 1(95 \% \mathrm{CI}=$ $7.96-8.75 \mathrm{mg} / \mathrm{l})$, in patients with isolated course of NAFLD was $6.55 \mathrm{mg} / 1(95 \% \mathrm{CI}=6.47-7.57 \mathrm{mg} /$ 1) $(\mathrm{p}<0.001)$. These results exceeded the control patients also showed statistically significant difference $(\mathrm{p}<0.001)$.

Significant differences between the groups were found in determining the lipid profile to assess the possibility of combining the mechanisms of dyslipidemia in patients with comorbid NAFLD and hypertension. Almost all indicators of the lipid profile of both examined groups had a significant difference 


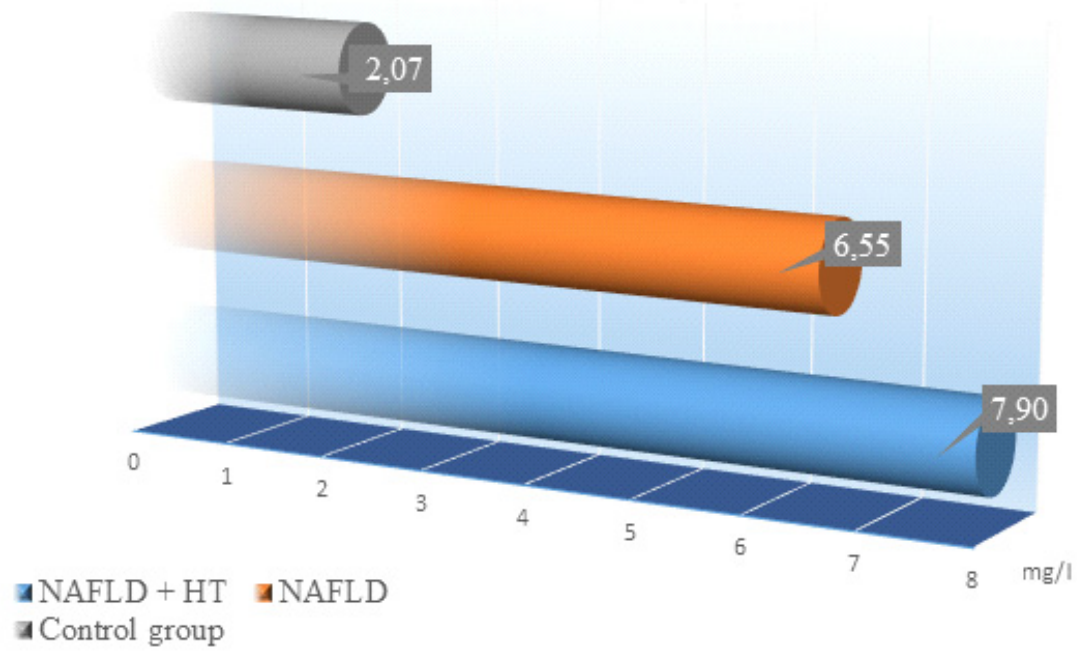

The levels of C-reactive protein in NAFLD patients depending on the presence of HT, mg/l

in comparison with the control indicators, except for HDL cholesterol in the comparison group. Comparison of lipid profile in patients with NAFLD against a HT background with isolated NAFLD individuals revealed significant differences in levels of total cholesterol, LDL cholesterol, HDL cholesterol and atherogenic coefficient. There was no significant difference between LDL cholesterol and triglycerides in the two groups (Table 4).

The obtained data confirm the idea of the prevalence of the type of hyperlipoproteinemia phenotype "IIb" in patients with HT, determine the serum lipid profile in patients with NAFLD as proatherogenic, and indicate the effect of concomitant hypertension on lipid metabolism in patients with NAFLD.

The study of the levels of markers of liver damage revealed similar deviations: significant differences between the groups of examined patients were found for all indicators. There was no statistically significant difference only in the group with isolated NAFLD in the assessment of alkaline phosphatase and De Ritis ratio in comparison with the parameters of almost healthy individuals. At the same time, only 12 patients from the main group had an AST/ALT index in

Lipid profile results in NAFLD patients depending on the presence of HT, mmol/l

\begin{tabular}{|c|c|c|c|c|}
\hline Indicator & $\begin{array}{c}\text { NAFLD and HT } \\
(n=63)\end{array}$ & $\begin{array}{l}\text { NAFLD } \\
(n=52)\end{array}$ & $\begin{array}{c}\text { Control group } \\
(n=20)\end{array}$ & $\begin{array}{c}\text { Reliability } \\
\text { between groups }\end{array}$ \\
\hline Total cholesterol, $\mathrm{mmol} / \mathrm{l}$ & $\begin{array}{c}6.78 \\
(95 \% \mathrm{Cl}= \\
6.60-6.97)\end{array}$ & $\begin{array}{c}5.93 \\
(95 \% \mathrm{Cl}= \\
5.77-6.08)\end{array}$ & $\begin{array}{c}4.00 \\
(95 \% \mathrm{Cl}= \\
3.76-4.24)\end{array}$ & $\begin{array}{l}\mathrm{p}_{1-2}<0.001 \\
\mathrm{p}_{1-3}<0.001 \\
\mathrm{p}_{2-3}<0.001\end{array}$ \\
\hline LDL cholesterol, mmol/l & $\begin{array}{c}4.11 \\
(95 \% \mathrm{Cl}= \\
3.99-4.44)\end{array}$ & $\begin{array}{c}3.14 \\
(95 \% \mathrm{Cl}= \\
2.97-3.45)\end{array}$ & $\begin{array}{c}2.28 \\
(95 \% \mathrm{Cl}= \\
2.25-2.65)\end{array}$ & $\begin{aligned} \mathrm{p}_{1-2} & =7.38 \\
\mathrm{p}_{1-3} & <0.001 \\
\mathrm{p}_{2-3} & <0.001\end{aligned}$ \\
\hline LDL cholesterol, mmol/l & $\begin{array}{c}0.78 \\
(95 \% \mathrm{Cl}= \\
0.74-0.82)\end{array}$ & $\begin{array}{c}0.61 \\
(95 \% \mathrm{Cl}= \\
0.57-0.66)\end{array}$ & $\begin{array}{c}0.50 \\
(95 \% \mathrm{Cl}= \\
0.45-0.56)\end{array}$ & $\begin{array}{l}\mathrm{p}_{1-2}<0.001 \\
\mathrm{p}_{1-3}<0.001 \\
\mathrm{p}_{2-3}=0.014\end{array}$ \\
\hline HDL cholesterol, mmol/l & $\begin{array}{c}1.01 \\
(95 \% \mathrm{Cl}= \\
1.01-1.09)\end{array}$ & $\begin{array}{c}1.19 \\
(95 \% \mathrm{Cl}= \\
1.14-1.24)\end{array}$ & $\begin{array}{c}1.165 \\
(95 \% \mathrm{Cl}= \\
1.13-1.28)\end{array}$ & $\begin{array}{l}\mathrm{p}_{1-2}<0.001 \\
\mathrm{p}_{1-3}<0.001 \\
\mathrm{p}_{2-3}=0.821\end{array}$ \\
\hline Triglycerides, $\mathrm{mmol} / \mathrm{l}$ & $\begin{array}{c}1.9 \\
(95 \% \mathrm{Cl}= \\
1.84-2.02)\end{array}$ & $\begin{array}{c}2.03 \\
(95 \% \mathrm{Cl}= \\
1.90-2.07)\end{array}$ & $\begin{array}{c}1.27 \\
(95 \% \mathrm{Cl}= \\
1.16-1.38)\end{array}$ & $\begin{array}{l}\mathrm{p}_{1-2}=0.124 \\
\mathrm{p}_{1-3}<0.001 \\
\mathrm{p}_{2-3}<0.001\end{array}$ \\
\hline Atherogenic coefficient & $\begin{array}{c}5.57 \\
(95 \% \mathrm{Cl}= \\
5.27-5.87)\end{array}$ & $\begin{array}{c}4.12 \\
(95 \% \mathrm{Cl}= \\
3.86-4.37)\end{array}$ & $\begin{array}{c}2.37(95 \% \mathrm{Cl}= \\
2.11-2.64)\end{array}$ & $\begin{array}{l}\mathrm{p}_{1-2}<0.001 \\
\mathrm{p}_{1-3}<0.001 \\
\mathrm{p}_{2-3}<0.001\end{array}$ \\
\hline
\end{tabular}

Note: $\mathrm{p}<0,05-$ the difference is statistically significant between groups;

$\mathrm{p}_{1-2}-$ the difference between the NAFLD + HT group and the isolated NAFLD group;

$\mathrm{p}_{1-3}$ - the difference between the NAFLD + HT group and the control group;

$\mathrm{p}_{2-3}$ - the difference between the isolated NAFLD group and the control group. 
the range $>1$, which can be considered a marker of fibrotic and cirrhotic changes in the liver (Table 5).

\section{Discussion}

The effect of concomitant hypertension on the clinical manifestation of NAFLD has been determined in various studies. Ampuero J. et al. showed that HT was independently linked to significant fibrosis in patients with NAFLD $(p=0.028)$. Also, investigation showed significantly low HDL in $9.6 \%$ and confirm the state of lipid metabolism in the patients who were examined.

The study of Ma J. included 1051 participants with and without NAFLD, and showed that baseline NAFLD was associated with increased odds of incident HT (OR 1.42; 95\% CI 1.15$1.76 ; p=0.001)$ and patients with hypertension at baseline had higher odds of NAFLD development (OR 3.34; 95\% CI 2.04-5.49) $(\mathrm{p}<0.03)$.

Table 5

Markers of liver damage in NAFLD patients depending on the presence of HT, IU/l

\begin{tabular}{|c|c|c|c|c|}
\hline Indicator & $\begin{array}{c}\text { NAFLD and HT } \\
(n=63)\end{array}$ & $\begin{array}{l}\text { NAFLD } \\
(n=52) \\
\end{array}$ & $\begin{array}{c}\text { Control group } \\
(n=20)\end{array}$ & Reliability between groups \\
\hline ALT, IU/I & $\begin{array}{c}79.00 \\
(95 \% \mathrm{Cl}= \\
80.00-86.98)\end{array}$ & $\begin{array}{c}69.00 \\
(95 \% \mathrm{Cl}= \\
65.29-70.79)\end{array}$ & $\begin{array}{c}20.00 \\
(95 \% \mathrm{Cl}= \\
18.77-23.92)\end{array}$ & $\begin{array}{l}\mathrm{p}_{1-2}<0.001 \\
\mathrm{p}_{1-3}<0.001 \\
\mathrm{p}_{2-3}<0.001\end{array}$ \\
\hline AST, IU/I & $\begin{array}{c}75.05 \\
(95 \% \mathrm{Cl}= \\
68.13-75.17)\end{array}$ & $\begin{array}{c}54.00 \\
(95 \% \mathrm{Cl}= \\
53.16-56.99)\end{array}$ & $\begin{array}{c}16.50 \\
(95 \% \mathrm{Cl}= \\
15.36-20.04)\end{array}$ & $\begin{array}{l}\mathrm{p}_{1-2}<0.001 \\
\mathrm{p}_{1-3}<0.001 \\
\mathrm{p}_{2-3}<0.001\end{array}$ \\
\hline De Ritis ratio (AST/ALT) & $\begin{array}{c}0.90(95 \% \mathrm{Cl}= \\
0.88-0.92)\end{array}$ & $\begin{array}{c}0.80(95 \% \mathrm{Cl}= \\
0.80-0.83)\end{array}$ & $\begin{array}{c}0.82(95 \% \mathrm{Cl}= \\
0.79-0.87)\end{array}$ & $\begin{array}{l}\mathrm{p}_{1-2}<0.001 \\
\mathrm{p}_{1-3}=0.005 \\
\mathrm{p}_{2-3}=0.439\end{array}$ \\
\hline$A F, I U / I$ & $\begin{array}{c}1840.00 \\
(95 \% \mathrm{Cl}= \\
1764.83- \\
1872.79)\end{array}$ & $\begin{array}{c}1150.00 \\
(95 \% \mathrm{Cl}= \\
1059.91-1213.17)\end{array}$ & $\begin{array}{c}1160.00 \\
(95 \% \mathrm{Cl}= \\
1032.76-1222.24)\end{array}$ & $\begin{array}{l}\mathrm{p}_{1-2}<0.001 \\
\mathrm{p}_{1-3}<0.001 \\
\mathrm{p}_{2-3}=0.826\end{array}$ \\
\hline GGTP, IU/I & $\begin{array}{c}64.00 \\
(95 \% \mathrm{Cl}= \\
63.31-70.53)\end{array}$ & $\begin{array}{c}57.83 \\
(95 \% \mathrm{Cl}= \\
55.08-60.57)\end{array}$ & $\begin{array}{c}28.15 \\
(95 \% \mathrm{Cl}= \\
23.84-32.46)\end{array}$ & $\begin{array}{l}\mathrm{p}_{1-2}<0.001 \\
\mathrm{p}_{1-3}<0.001 \\
\mathrm{p}_{2-3}<0.001\end{array}$ \\
\hline
\end{tabular}

Note: $\mathrm{p}<0,05-$ the difference is statistically significant between groups;

$\mathrm{p}_{1-2}$ - the difference between the NAFLD + HT group and the isolated NAFLD group;

$\mathrm{p}_{1-3}$ - the difference between the NAFLD + HT group and the control group;

$\mathrm{p}_{2-3}$ - the difference between the isolated NAFLD group and the control group.

hypertriglyceridemia in $23.6 \%$ of patients with comorbid course of NAFLD on the background of HT was found [1].

The possibility of the two-way relationship between these diseases remains under study. Prospective cohort study of Liu P. et.al. included 6704 eligible hypertension-free subjects and 9328 NAFLD-free subjects and bidirectional association between NAFLD and hypertension was also shown. Among 6704 participants free of HT at baseline, 2561 (38.2\%) developed hypertension and 2289 (24.5\%) participants developed NAFLD on the background of HT. Patients with NAFLD and HT had significantly higher mean waist circumference and BMI, levels of serum lipids (TC, TG, and LDL-c). This study provided evidence that development and persistence of hypertension were the high risk factors for incident and more severe course of NAFLD in patients without T2D2 or obesity [10].

These conclusions contradict the results of anthropometry obtained in this study, but they
It was also found significant differences in the glucose level, as well as the state of lipid metabolism in patients with NAFLD and accompanied HT. The study showed possibility of insulin resistance influence on linking the bidirectional association of fatty liver and CVD risk factors throw overproduction of VLDL and increased influx of free fatty acids into the liver from adipose tissue [13].

According to Aneni E. C. et al., more prevalent NAFLD may occur early in the development of HT, even in conditions of the absence of other metabolic risk factors. The authors concluded that controlling blood pressure levels among even non-obese hypertensive patients may be important in preventing or limiting NAFLD [2].

Hypertensive patients in this research had significantly higher waist circumference values $(98.52 \pm 12.52 \mathrm{~cm})$ and body mass index $(29.99 \pm 1.41 \mathrm{~kg} / \mathrm{m} 2)$, higher glycaemia level $(124.14 \pm 45.33 \mathrm{mg} / \mathrm{dL})$, higher level of triglycerides (195.27 $\pm 74.52 \mathrm{mg} / \mathrm{dL})$, and hs-CRP 
$(0.53 \pm 0.44 \mathrm{mg} / \mathrm{dL})$ [18]. In fact, this is in line with the results of this study, which also point to the importance of blood pressure control due to the negative impact of hypertension on the manifestation of NAFLD.

Ilan, Y in showed that the prevalence of NAFLD in cases of normal blood pressure, prehypertension, and HT reaches 16.5, 37.5, and $59.3 \%$, respectively. In multivariate analyses, prehypertension and hypertension have been associated with elevated risk of presence NAFLD. High hs-CRP values was found in hypertensive patients and it was considered as an independent risk factor for HT. Authors concluded that this biomarker can aggravate hypertension by participating in local and systemic inflammatory responses [8]. Significant differences in the CRP level obtained during the examination of patients with comorbid and isolated NAFLD course also confirm this statement.

Summary from 19 prospective studies by Lonardo A. at al. suggest that HT can lead to differences in NAFLD course and condition the rapid deterioration of fatty liver patients and combination of this pathologies could be a precursor of the metabolic syndrome [11].

\section{Conclusions}

The obtained data suggest that the presence of concomitant hypertension in patients with NAFLD introduce certain deviations in the clinical manifestation of the disease, which is manifested by a significant increase in the incidence of subjective signs of liver damage, dyspeptic and asthenic syndrome. The results indicate a significant impact of HT on the quality of life of patients, which can be manifested by significant changes in the patient's subjective perception of their physical and psychological condition. The course of both isolated NAFLD and comorbidity NAFLD with HT is accompanied by changes in carbohydrate and lipid profile and levels of nonspecific marker of inflammation, C-reactive protein, which confirmed the pathophysiological role of metabolic disorders and chronic systemic low-grade inflammation in NAFLD. The combination of these problems leads to a significant increase in the severity of deviations in these indicators, which makes it possible to consider HT as a trigger factor for the progression of NAFLD in patients with this "nosological tandem".

\section{References}

1. Ampuero, J., Aller, R., Gallego-Duran, R., Crespo, J., Calleja, J.L., Garcia-Monzon, C.,... Romero Gomez, M. (2020). Significant fibrosis predicts new-onset diabetes mellitus and arterial hypertension in patients with NASH. Journal of Hepatology, 73(1), 17-25. doi: 10.1016/j.jhep.2020.02.028.

2. Aneni, E. C., Oni, E. T., Martin, S. S., Blaha, M. J., Agatston, A. S., Feldman, T.,...Nasir K. (2015). Blood pressure is associated with the presence and severity of nonalcoholic fatty liver disease across the spectrum of cardiometabolic risk. Journal of Hypertension, 33 (6), 1207-1214. doi: 10.1097/ HJH.0000000000000532. PMID: 25693058.

3. Babak O., Zajceva M. (2018). Ocinjuvannja pokaznykiv kardiogemodynamiky u hvoryh na arterial'nu gipertenziju ta nealkogol'nu zhyrovu hvorobu pechinky zalezhno vid genotypiv polimorfizmu A1166S gena receptora angiotenzynu II pershogo typu [Assessment of cardiac hemodynamics indicators in patients with arterial hypertension and non-alcoholic fatty liver disease depending on angiotensin II type 1 receptor A1166C gene polymorphism]. Zaporozhskyj medycynskyj zhurnal, Vol. 20, no 3, pp. 305-308.

4. Babak, O. Ya., Prosolenko, K. O., Klimenko, M.I., Panchenko, G.Yu. (2020). Porivnjal'na harakterystyka shem tryvalogo kompleksnogo likuvannja hvoryh na nealkogol'nu zhyrovu hvorobu pechinky u pojednanni z gipertonichnoju hvoroboju [Comparative characteristics of long-term complex treatment regimens for patients with non-alcoholic fatty liver disease in combination with hypertension]. Ukrai'ns'kyj terapevtychnyj zhurnal, no 1, pp. 6-14. doi: 10.30978/UTJ2020-1-6

5. Bonnet, F., Gastaldelli, A., Pihan-Le Bars, F., Natali, A., Roussel, R., Petrie J. (2017). Gammaglutamyltransferase, fatty liver index and hepatic insulin resistance are associated with incident hypertension in two longitudinal studies. Journal of Hypertension, 35, 493-500.

6. Fadjejenko, G. D., Kushnir, I. E., Chernova, V. M. (2018). Vzajemozv'jazok mizh rivnem syrovatkovyh markeriv zapalennja ta metabolichnymy porushennjamy pry nealkogol'nij zhyrovij hvorobi pechinky [The relationship of serum inflammatory markers with metabolic disorders at the non-alcoholic fatty liver disease]. Suchasna gastroenterologija, 5 (103), 7-12. doi: 10.30978/MG-2018-5-7

7. Fracanzani, A. L., Petta, S., Lombardi, R., Pisano, G., Russello, M., Consonni, D., ... Fargion, S. (2017). Liver and Cardiovascular Damage in Patients With Lean Nonalcoholic Fatty Liver Disease, and 
Association With Visceral Obesity. Clinical Gastroenterology and Hepatology, 15(10), 1604-1611. doi:10.1016/j.cgh.2017.04.045

8. Ilan, Y. (2018). Analogy between non-alcoholic steatohepatitis (NASH) and hypertension: a stepwise patient-tailored approach for NASH treatment. Annals of gastroenterology, 31(3), 296-304.

9. Kim, M.J. Non-alcoholic Fatty Liver Disease, Cardio-metabolic Syndrome and Hypertension: One Concept Fits Multi-systemic Presentations. (2020). Korean Circulation Journal, 50(8), 706-708. doi: 10.4070/kcj.2020.0217.

10. Liu, P., Tang, Y., Guo, X., Zhu, X., He, M., Yuan, J., ... Yao, P. (2018). Bidirectional association between nonalcoholic fatty liver disease and hypertension from the Dongfeng-Tongji cohort study. Journal of the American Society of Hypertension. doi:10.1016/j.jash.2018.06.013

11. Lonardo, A., Ballestri, S., Marchesini, G., Angulo, P., Loria, P. (2015). Nonalcoholic fatty liver disease: a precursor of the metabolic syndrome. Digestive and liver disease: official journal of the Italian Society of Gastroenterology and the Italian Association for the Study of the Liver, 47, 181-190.

12.Lonardo, A., Nascimbeni, F., Mantovani, A., Targher, G. (2017). Hypertension, diabetes, atherosclerosis and NASH: Cause or consequence? Journal of Hepatology, 68(2), 335-352. doi: 10.1016/ j.jhep.2017.09.021. Epub 2017 Nov 6. PMID: 29122390.

13.Ma, J., Hwang, S.-J., Pedley, A., Massaro, J. M., Hoffmann, U., Chung, R. T., ... Long, M. T. (2017). Bi-directional analysis between fatty liver and cardiovascular disease risk factors. Journal of Hepatology, 66(2), 390-397. doi:10.1016/j.jhep.2016.09.022

14. Marunchyn N., Dynnyk O., Kovalerenko L. (2017). Zastosuvannja pryncypu mul'typarametrychnogo ul'trazvuku dlja diagnostyky nealkogol'noi' zhyrovoi' hvoroby pechinky v pacijentiv iz cukrovym diabetom 2-go typu [Using the principle of multiparametric ultrasound for the diagnosis of nonalcoholic fatty liver disease in patients with type 2 diabetes mellitus]. Mezhdunarodnyi Endokrinologicheskii Zhurnal, no 13, pp.171-176. doi: 10.22141/2224-0721.13.2.2017.100608

15. Oikonomou, D., Georgiopoulos, G., Katsi, V., Kourek, C., Tsioufis, C., Alexopoulou, A., Tousoulis, D. (2018). Non-alcoholic fatty liver disease and hypertension. European Journal of Gastroenterology \& Hepatology, 30(9), 979-985. doi:10.1097/meg.000000000001191

16.Singh, S., Allen, A.M., Wang, Z., Prokop, L.J., Murad, M.H., Loomba, R. (2015). Fibrosis progression in nonalcoholic fatty liver vs. nonalcoholic steatohepatitis: a systematic review and metaanalysis of paired-biopsy studies. Clinal Gastroenterology and Hepatology, 13, 643-654. doi: 10.1016/ j.cgh.2014.04.014.

17.Tiwari-Heckler, S., Gan-Schreier, H., Stremmel, W., Chamulitrat, W., Pathil, A. (2018). Circulating Phospholipid Patterns in NAFLD Patients Associated with a Combination of Metabolic Risk Factors. Nutrients, 10(5), 649. doi: 10.3390/nu10050649.

18.Tofano, R. J., Barbalho, S. M., Bechara, M. D., Quesada, K., Mendes, C. G., \& Oshiiwa, M. (2017). Hypertension, C Reactive Protein and Metabolic Profile: What is the Scenario in Patients Undergoing Arteriography?. Journal of clinical and diagnostic research : JCDR, 11(8), BC19-BC23. https://doi.org/ $10.7860 / \mathrm{JCDR} / 2017 / 26595.10456$

19.Wu, S.-J., Zou, H., Zhu, G.-Q., Wang, L.-R., Zhang, Q., Shi, K.-Q., .. Zheng, M.-H. (2015). Increased Levels of Systolic Blood Pressure Within the Normal Range Are Associated With Significantly Elevated Risks of Nonalcoholic Fatty Liver Disease. Medicine, 94(19), e842. doi:10.1097/ md.0000000000000842

20. Younes, R., \& Bugianesi, E. (2019). NASH in Lean Individuals. Seminars in Liver Disease, 39(1), 86-95. doi:10.1055/s-0038-1677517

21.Zhang, Y., Zhang, T., Zhang, C. (2015). Identification of reciprocal causality between non-alcoholic fatty liver disease and metabolic syndrome by a simplified Bayesian network in a Chinese population. The BMJ, 5, e008204. doi: 10.1136/bmjopen-2015-008204

Received: 23-Aug-2020 Accepted: 20-Sep-2020 